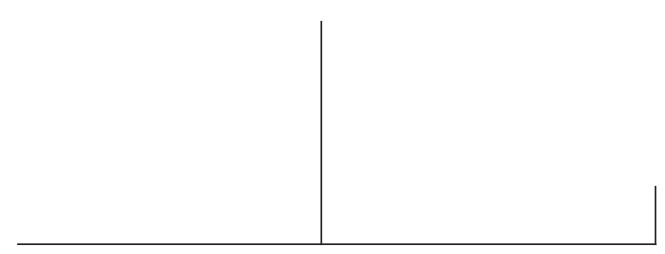

\title{
Catástrofe e representação. Notas para uma teoria geral da Psicopatologia Fundamental*
}

\author{
Manoel Tosta Berlinck
}

\begin{abstract}
Este artigo comenta, de forma detalhada, o trabalho de Sigmund Freud, "Neuroses de transferência: uma síntese”, que é considerado pelo autor como uma teoria geral da natureza psicopatológica da humanidade. Nessa perspectiva, porque a humanidade está submetida ao desejo, a paixão a torna psicopatológica. A partir, então, do pressuposto de que o humano é uma espécie psicopatológica, o autor tece comentários sobre a nosologia freudiana, sua importância na atualidade e suas limitações, formulando, assim, um amplo projeto de pesquisa que está sendo desenvolvido na psicanálise.
\end{abstract}

* Versão modificada da conferência pronunciada no III Congresso Brasileiro de Psicopatalogia Fundamental, em abril de 1998. 


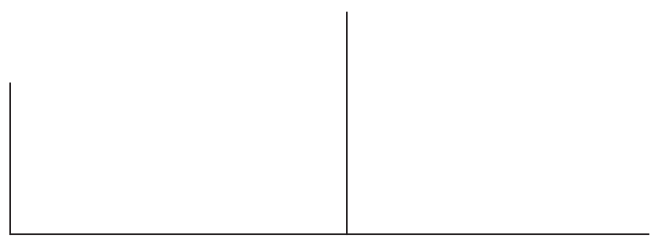

Por toda a parte nos resta ainda uma alegria. A dor pura entusiasma. Quem sobe sobre a própria Miséria, está mais alto. E é magnífico saber que só Na dor sentimos bem a liberdade da alma.

Hölderlin, Hyperion

A partir do momento - final do século XIX e início do século $X X$ - que Freud descobriu o inconsciente sexual, inicialmente entendido como um conjunto de conteúdos representativos que é desalojado de nossa consciência porque é desagradável, porque produz sofrimento e, mais tarde, como uma dimensão de nossa alma que é diretamente inacessível por nossos recursos racionais, o homem passou a ser concebido como um sujeito propriamente psicopatológico, ou seja, portador de um excesso, de uma dor, de um sofrimento psíquico a respeito do qual fala sem parar, ainda que não o diga constantemente.

$\mathrm{Na}$ perspectiva inaugurada por Freud não há normalidade, ou melhor, a normalidade, além de ser um conceito meramente estatístico, seria um estado para sempre perdido - um tal de estado nirvânico em que não haveria dor nem representação.

A normalidade para sempre perdida é como o Rosebud - trenó do Cidadão Kane: está constantemente presente em todos os nossos atos psíquicos que visam incessantemente alcançar esse estado para sempre perdido. A busca incansável da normalidade para sempre perdida é a mais potente central geradora de energia no ser humano que o leva às mais incríveis invenções que são sempre sintomas, isto é, tentativas mais ou menos fracassadas de cura do excesso, da dor, do pathos, do sofrimento (cf. Berlinck, 1998). Dentre as incríveis invenções do ser humano visando a recuperação da normalidade nada se compara à palavra e à fala, ou seja, à capacidade orgânica de pronunciar palavras. A palavra e a fala são fenômenos muito complexos que, para serem criados, exigiram um fantástico esforço criativo que só uma grande ameaça pode suscitar. Dentre as diversas propriedades da palavra e da fala há uma que merece particular atenção. Trata-se da capacidade de representação. A palavra e a fala são atos performáticos que possuem sempre a característica de representar. 


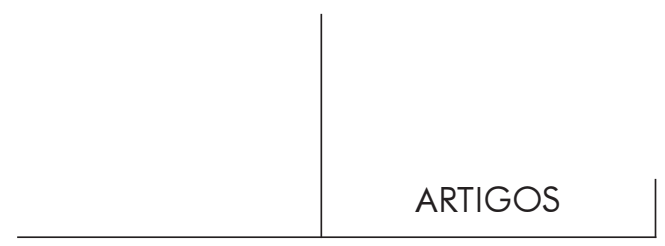

Entretanto, somos, com muita freqüência, levados à palavra e à fala sem nos preocuparmos com sua representação. Assim, quando perguntamos a alguém: Tudo bem? Tudo bom? não temos a menor intenção (pelo menos explícita) de suscitarmos no outro uma introspecção que deveria levar bastante tempo para que pudesse responder essas complexas indagações com alguma consistência. Quando o ser humano se apossa dessa propriedade, a palavra e a fala servem para a constituição de experiência, ou seja, um conjunto de conhecimentos individuais ou específicos que constituem aquisições vantajosas acumuladas historicamente pela humanidade.

$\mathrm{Na}$ visão freudiana, o estado nirvânico, que corresponderia a uma normalidade edênica que se encontra descrita no livro do Gênesis, foi perdido graças a uma catástrofe ecológica denominada "era glacial" em que a crosta da terra se congelou e o hominídeo sofreu conseqüências tão avassaladoras que foi obrigado a se transformar em humano. Assim, por exemplo, foi obrigado a abandonar a posição quadrúpede e adquirir a posição bípede para alcançar alimentos em arbustos e árvores, já que o verde que nascia rente à superfície da terra ficou congelado.

A aquisição da posição ereta não ocorreu sem perdas. O hominídeo perdeu contato com a regularidade sexual que se sustentava pelo olfato. Numa conhecida nota de rodapé existente em "O mal-estar na civilização" (1930/1974) Freud diz:

A periodicidade orgânica do processo sexual persistiu, é verdade, mas seu efeito sobre a excitação sexual psíquica foi invertido. Parece mais provável que essa modificação se tenha vinculado à diminuição dos estímulos olfativos, através dos quais o processo menstrual produzia efeito sobre a psique masculina. Seu papel foi assumido pelas excitações visuais, que, em contraste com os estímulos olfativos intermitentes, conseguiram manter um efeito permanente. ... A própria diminuição dos estímulos olfativos parece ser conseqüência de o homem ter-se erguido do chão, de sua adoção de uma postura ereta; isso tornou seus órgãos genitais, anteriormente ocultos, visíveis e necessitados de proteção, provocando desse modo sentimento de vergonha nele. (pp. 119-120)

A catástrofe glacial produziu, então, num primeiro momento, uma escassez de alimentos que acabou provocando a posição ereta que levou à perda de contato com a regularidade sexual. Esta, por sua vez, acabou sendo uma enorme ameaça para a humanidade, já que poderia desencadear o extermínio da espécie. O cheiro da hominídea fértil, hoje completamente perdido e encoberto por outros aromas naturais e artificiais, deixou o hominídeo completamente perdido e angustiado.

No fantástico texto mal denominado em português "Neuroses de transferência: uma síntese" (1914/1985), já que se trata de uma visão de conjunto, Freud apresenta, de forma muito clara, sua concepção de que o psiquismo 


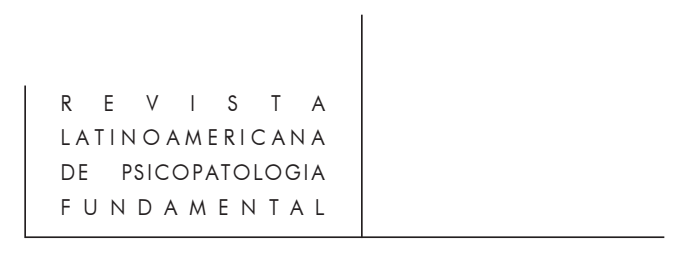

humano é psicopatológico, a partir da catástrofe glacial. Segundo ele, a história do desenvolvimento da energia sexual, denominada libido, repete uma parte do desenvolvimento filogenético bem mais antiga do que o do eu, o primeiro talvez repetindo as condições dos animais vertebrados, enquanto o último depende da história da espécie humana. Observa, então, Freud que:

Existe uma série à qual podemos atar várias idéias de longo alcance. Essa série aparece quando colocamos as psiconeuroses (não somente as neuroses de transferência) numa ordem de acordo com o momento em que costumam se apresentar na vida individual. Nesse caso, temos como a mais precoce a neurose de angústia, a quase incondicional; segue-se-lhe a histeria de conversão (mais ou menos a partir do quarto ano); e ainda um pouco mais tarde, na pré-puberdade (9-10 anos), aparece, nas crianças, a neurose obsessiva. Não há neuroses narcisistas na infância. Destas, a demência precoce (conhecida hoje como esquizofrenia), em sua forma mais clássica, é uma doença da puberdade; a paranóia aproxima-se dos anos de maturidade como também a melancolia-mania. (p. 73)

Portanto, a seqüência é a seguinte:

Histeria de angústia - Histeria de conversão - Neurose obsessiva - Demência precoce - Paranóia - Melancolia-mania.

A partir daí, Freud vai estabelecer uma outra sequiência, esta filogenética, que ocorre realmente em paralelo com a sequiência cronológica das neuroses. "Apenas para isso", diz ele, "é necessário divagar, bastando-se alguns elos hipotéticos." (p. 74)

Essa divagação fundamental parte da idéia atribuída a Fritz Wittels segundo a qual o primata teria passado sua existência num ambiente extremamente rico, satisfazendo todas as suas necessidades. Ferenczi, em Thalassa. Ensaio sobre a teoria da genitalidade (1914/1990) foi o primeiro a expor que o desenvolvimento ulterior desse primata realizou-se sob a influência dos destinos geológicos da Terra e, especialmente, das agruras dos tempos glaciais que teriam exercido o estímulo para o desenvolvimento cultural. Essa idéia de Ferenczi serviu muito para que Freud desenvolvesse sua grande teoria psicopatológica da humanidade.

Apresentando a idéia de Ferenczi, Freud fica tentado a reconhecer, nas três disposições para a histeria de angústia, a histeria de conversão e a neurose obsessiva, regressões a fases pelas quais toda a espécie humana teve que passar do começo ao fim dos tempos glaciais. Em outras palavras, Freud postula, a partir de Wittels e Ferenczi, uma universalidade psicopatológica que, inicialmente, foi uma série de soluções criativas diante da catástrofe glacial. O homem é, assim, um ser da catástrofe e é a partir dela, e de uma capacidade criativa que se transforma em repetição, que o ser humano é uma espécie psicopatológica. Assim como naquela época todos os homens passavam por essa experiência, hoje isso ocorre apenas com uma parcela, em virtude da predisposição herdada acionada 


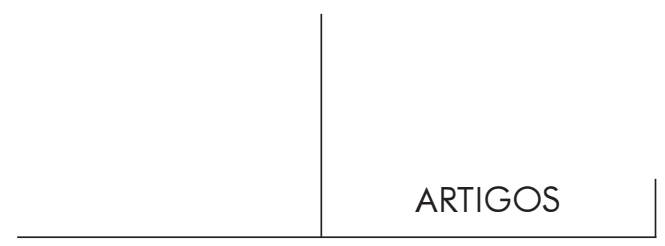

por novas experiências. Os quadros não podem naturalmente ser superponíveis, diz ainda Freud, porque a neurose contém mais do que a regressão traz consigo. Ela é também a expressão da resistência contra essa regressão, um compromisso entre as coisas antigas dos tempos primitivos e a exigência do culturalmente novo.

\section{Angústia, dor e medo}

Como primeira colocação, afirmaria, portanto, que sob a influência das privações impostas pelo desencadeamento da era glacial, a humanidade em geral tornou-se angustiada. O mundo externo, que era até então preponderantemente amistoso, propiciando qualquer satisfação, transformou-se num acúmulo de riscos eminentes. Havia toda razão para a angústia real diante de qualquer fato novo. A libido sexual, contudo, não perdeu de imediato seus objetos, sabidamente humanos, porém compreende-se que o eu ameaçado na sua existência acabaria desistindo, até certo ponto, do investimento objetal. Mantendo a libido no eu, transformou em angústia real o que antes havia sido libido objetal. Vemos, pois, na angústia infantil, que a criança, no caso de ausência de satisfação, não só transforma a libido objetal em angústia real diante de algo estranho, como também tende, em geral, a angustiar-se diante de qualquer coisa nova. Temos sustentado uma longa discussão a respeito de qual é a primeira: a angústia real ou a angústia nostálgica. Se a criança transformar sua libido em angústia real, é porque para ela sua libido é demasiadamente grande, perigosa, chegando assim à representação do perigo; ou, ao contrário, cede a uma angústia de natureza mais geral e por esta aprende a temer sua libido insatisfeita. Inclinamo-nos a aceitar a primeira, antepondo a angústia nostálgica, mas para isso falta-nos uma disposição especial. Teríamos de explicála como uma inclinação infantil geral. Contudo, a consideração filogenética parece reconciliar esta discussão em favor da angústia real e faz-nos supor que uma parcela das crianças traz consigo aquele temor primitivo da era glacial, o que agora induz a tratar a libido insatisfeita como um perigo externo. $\mathrm{O}$ excesso relativo de libido proviria da mesma base, possibilitando novas aquisições à angústia. Pelo menos, a discussão sobre a histeria de angústia falaria a favor da preponderância da disposição filogenética sobre todos os demais fatores. (pp. 74-75)

Neste ponto, gostaria de interromper a narrativa da teoria psicopatológica da humanidade construída por Freud para formular algumas observações que pretendem realçar certos aspectos dessa mesma teoria e colocar alguns problemas que precisam ser pesquisados.

O que sempre é o mais primitivo, em Freud, é o Eden, o princípio do nirvana, o princípio do prazer. Há, nessa concepção, uma rica fantasia filogenética que, devidamente explorada, muito nos ensinaria sobre os grandes esforços contemporâneos para encontrar um estado de plena satisfação. A ciência em geral, e mais especificamente a psiquiatria biológica, talvez seja a mais promissora e 


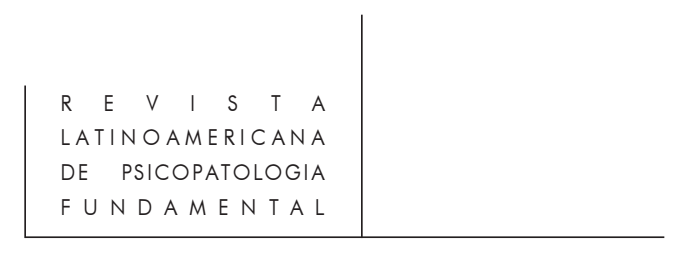

potente ideologia contemporânea a respeito de um retorno ao Éden para sempre perdido. Segundo essa concepção o excesso, o sofrimento, o pathos, a dor humana são geneticamente herdados com o que, certamente, Freud está de acordo. Ora, se graças à engenharia genética o homem conseguisse extirpar o gene da angústia, uma outra humanidade surgiria. Resta saber, entretanto, se sem angústia o ser humano não perderia qualquer capacidade de defesa diante de um perigo externo. Se assim fosse, morreríamos todos como carneirinhos: sem esboçar qualquer defesa, inocentes e felizes, sem qualquer angústia.

A angústia, por sua vez, sendo inicialmente real, é produzida por um desligamento do objeto e o retorno da libido para o corpo do hominídeo. Trata-se, então, de um narcisismo primeiro, de um narcisismo primitivo, que é anterior ao narcisismo primário, que ocorre graças ao desejo parental, e o narcisismo secundário, que é uma repetição do primitivo. O narcisismo primário e o secundário foram estudados por Magalhães (in Berlinck, 1985), mas esse narcisismo primitivo, ainda insuficientemente compreendido, talvez seja o responsável pela pulsão, entendida, aqui, como força que não obedece mais ao instinto. Em outras palavras, é o desligamento do objeto que vai romper o circuito da necessidade regido pelo instinto e vai inaugurar o circuito da pulsão regido pelo prazer.

Porém, há um problema que se encontra implícito nessa dinâmica. Qual a natureza da força que produzia os movimentos do hominídeo e da hominídea antes mesmo do aparecimento da pulsão? A resposta é, à primeira vista, óbvia. A dinâmica do hominídeo e da hominídea, antes do início da catástrofe glacial, seria regida pela mera necessidade da sobrevivência da espécie. A força regente seria, então, o instinto. Entretanto, no indispensável Dicionário comentado do alemão de Freud, Luiz Hanns (1996), ao pesquisar o campo semântico coberto pelo termo Trieb comenta que:

... em alemão podem-se designar com a palavra Trieb diferentes dimensões e formas pelas quais as forças impelentes da Natureza podem se manifestar.

Tais forças podem, esquematicamente, ser classificadas em quatro níveis de manifestação: da Natureza em geral, do Biológico nas Espécies, no Indivíduo da Espécie e para o Indivíduo. Cada nível também reproduz em si uma escala que conduz do mais geral ao mais específico.

Assim os Triebe podem referir-se às "grandes forças impulsionadoras", algo semelhante a princípios universais que regem todo vivente. Visam a autopreservação, a reprodução etc.

Podem referir-se, ainda, à manifestação biológica dessas forças universais nas espécies: as poderosas forças biológicas básicas (o "instinto" de mamar, o gregarismo etc.).

Ainda dentro da esfera biológica, o termo serve para designar pulsões biológicas específicas (uma verdadeira miríade de "instintos" do cotidiano, a tendência de tocar, chupar, morder etc.). 


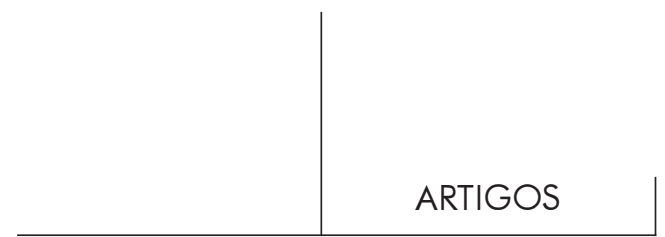

Também se utiliza o Trieb para aludir à manifestação da natureza no indivíduo como fenômeno fisiológico e somático (os estímulos, os reflexos, a energia circulante etc.) e, finalmente, para nomear a representação desse conjunto articulado, quando sentido ao nível íntimo e singular pelo sujeito como ânsia, impulso e vontade.

Tal divisão esquemática é apenas uma tentativa de explicitar ao leitor nãoalemão a polissemia do termo. No seu emprego psicanalítico, tais dimensões nem sempre podem ser mantidas em separado, entrelaçam-se e se manifestam de formas diversas.

Entretanto, apesar de reformular repetidas vezes sua teoria pulsional e movimentar-se ao longo de todo esse arco de possibilidades que lingüisticamente o termo alemão permite abarcar, Freud mantém-se, ao longo de toda a obra, próximo dos mencionados aspectos denotativos e conotativos de Trieb, algo indeterminado, poderoso, anterior ao instinto, algo que vem de alhures (impessoal, atemporal) e que coloca o indivíduo em movimento.

Em nível mais geral, trata-se de uma força poderosa, indeterminada, atemporal, arcaica e própria do ser vivo. ... Essa energia propulsora de origem indeterminada, que jaz sob os numerosos pequenos instintos, é gerada, ao nível do sujeito, conforme princípios que transcendem o indivíduo (pulsões de vida articuladas com princípios biológicos da espécie etc.) e o sujeita aos desígnios da biologia em geral. Neste sentido, pode-se dizer que a pulsão designa algo que é a própria base e condição dos instintos específicos. (pp. 350-351)

Nesta perspectiva, a pulsão seria, então, anterior ao instinto; uma força indeterminada e atemporal que vai se moldando segundo as vicissitudes dos movimentos do hominídeo e da hominídea. Ora, a pulsão que move o instinto é a mesma que constitui a libido. Assim, a ruptura do instinto, regido pela necessidade que a catástrofe glacial provoca, vai constituir a libido que está voltada para o prazer. Mas isso não quer dizer que a necessidade e o instinto desaparecem, pois, se assim fosse, a espécie já teria desaparecido num oceano hedonista. A ruptura do circuito instintual em favor do circuito prazeroso não implica, portanto, numa descontinuidade radical. Tanto o instinto como o prazer são pulsionais, vale dizer, biológicos (bios = vida, $\operatorname{logos}=$ discurso, fala, lógica), corporais, próprios do hominídeo e da hominídea. Não há, em Freud, um soma e uma psique. A teoria psicopatológica geral da humanidade é somática, eminentemente biológica e naturalista.

O fator responsável pela humanidade do ser humano, nessa teoria psicopatológica da humanidade, seria a catástrofe, ou seja, a violência que ameaça a espécie vinda do exterior. É essa violência que permite a modificação de posição corporal e provoca a saída do estado edênico para o estado humano. Sabe-se muito pouco ainda sobre essa fundamental passagem, mas é certo que o rompimento do equilíbrio nirvânico - provocado pela violência da catástrofe - 


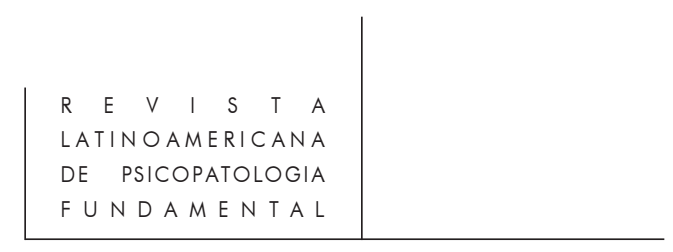

permitiu que o investimento libidinal no objeto se voltasse para o corpo do primata e começasse a produzir angústia. A humanidade nasce, então, angustiada, vale dizer, nasce criativa, pois essa angústia inicial é uma tremenda invenção. Ela só passa a ser doença com a repetição, ou seja, com o mecanismo herdado que produz angústia automaticamente, sem levar em consideração o que está ocorrendo no exterior. Aquilo, então, que foi uma grande invenção se transformou, por transferência, em neurose, em histeria de angústia. Ou seja, a repetição ocupa o espaço da criação. Trata-se, aqui, de uma verdadeira cronificação do organismo e do psiquismo nascente que só pode se livrar parcialmente disso se conseguir transformar a repetição em experiência, recuperando, assim, sua criatividade originária.

Essas considerações nos colocam outros problemas importantes que precisam ser analisados.

Em primeiro lugar, as vicissitudes dessa passagem do estado nirvânico para o angustiado coloca o problema da natureza da própria natureza. Em outras palavras, a natureza que se representa é uma natureza que faz parte da cultura. Quando digo, por exemplo, que a Mata Atlântica faz parte da natureza e precisa ser preservada, estou concebendo uma natureza que faz parte da cultura porque possui representação. Há, entretanto, uma outra natureza, sem representação, porque é anterior à cultura. Essa natureza sem representação possui algum registro no homem? Ferenczi, por exemplo, defende o ponto de vista de que o trauma inclui uma dimensão real irrepresentável. A inscrição dessa dimensão do trauma dar-se-ia justamente com o trauma primitivo, próprio da espécie, que produz o primeiro movimento áutico da libido. Como o primata era um ser da natureza, esta estava investida como objeto. A catástrofe glacial produz um desligamento do objeto e um retorno da libido para o corpo do primata trazendo, consigo, a identificação primitiva que inclui a natureza. É essa identificação primitiva que permite a Freud dizer que o homem busca sempre o estado nirvânico que prescinde da representação.

Ora, talvez seja essa identificação primitiva com a natureza irrepresentável que encontra, no autismo, um importante e complexo testemunho da natureza filogenética da psicopatologia. O autismo não faz parte explícita das psiconeuroses nem das neuroses de transferência na grande teoria psicopatológica da humanidade desenvolvida por Freud. Entretanto, a partir de Kanner, e de numerosas pesquisas contemporâneas sobre o assunto, fica-se com a conclusão, mesmo que provisória, de que o autismo é uma doença em que a criança parece não ser capaz de ultrapassar a natureza em direção à cultura. $\mathrm{O}$ autismo seria, então, uma manifestação cultural da natureza anterior à catástrofe glacial - um mundo silencioso, sem palavra, sem ruído e equilibrado, com movimentos repetitivos e padronizados representando a regularidade lá existente. Qualquer som ou 


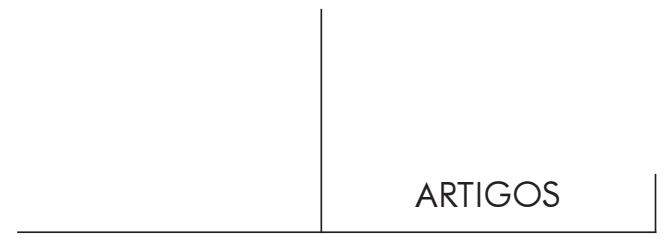

movimento que possa ameaçar o equilíbrio autista produz um intenso sentimento de terror que representa o desamparo diante da catástrofe. Além disso, o tempo do autismo seria o determinado pelo ciclo natural e não por eventos do mundo da cultura (ainda que natureza e biologia, tal como as concebemos hoje, sejam eminentemente culturais). (Rocha, 1997)

Frances Tustin, em seu último trabalho denominado “A perpetuação de um erro" (1995), declara que

... os estudos feitos com bebês por pesquisadores de muitos países ... mostraram, finalmente, que não há um estágio infantil normal de autismo primitivo para o qual o autismo infantil poderia ser uma regressão. Essa tem sido a hipótese da tendência principal, no que concerne à etiologia do autismo infantil, à qual muitos terapeutas psicanalíticos se subscreveram, especialmente nos Estados Unidos e na Europa. Essa hipótese defeituosa, baseada em premissas incompletas e inacabadas, tem sido como um vírus que penetrou e distorceu formulações clínicas e teóricas. Ela perpetuou essas distorções e obstruiu comunicações entre pesquisadores psicodinâmicos com crianças autistas. Obstruiu também a comunicação com os nossos colegas junguianos, por exemplo, com o Dr. Michael Fordham, cujo modelo é o de um "eu primário" que naturalmente se desenvolve (ou não, como no autismo) para alcançar e tomar o seu contorno. (p. 63)

Tustin deixa de lado, portanto, a idéia de que o autismo contém uma regressão para concebê-lo como primitivo. Ora, essa concepção, imediatamente, nos remete a um limite entre um estado "natural" e outro, humano, que é propriamente filogenético. Nesse estado natural da espécie não há regressão possível. Na passagem desse estado para o libidinal é que o autismo se manifesta pela primeira vez.

O artigo de Marília Amaro da Silveira Modesto Santos denominado "A trajetória de um autista e suas implicações com a temporalidade", publicado no primeiro número da Revista Latinoamericana de Psicopatologia Fundamental (1998), não só chama a atenção para a manifestação do tempo no autismo, como abre importantes perspectivas clínicas a respeito da temporalidade nas neuroses de transferência e nas psiconeuroses. Nesse sentido, o autismo seria uma resposta inventiva da humanidade diante da catástrofe glacial e seria, mesmo, anterior à angústia. Além disso, o autismo seria um estado muito generalizado, uma condição mesma da espécie humana. Ora, será que esse autismo primitivo e generalizado não é o vazio, o nada, a ausência? (Fédida, 1978)

A contribuição de Antonio Ricardo Rodrigues da Silva (1997) - com base em pesquisa iniciada no Centro de Pesquisa em Psicanálise e Linguagem - CPPL do Recife e elaborada no Laboratório de Psicopatologia Fundamental da PUC de São Paulo - onde concebe um mito da autoctonia segundo o qual a criança autista seria desejada e concebida pelos pais como um ser da natureza aponta, também, 
para uma direção filogenética dessa doença. Essa e outras pesquisas em andamento no Laboratório de Psicopatologia Fundamental da PUC-SP, junto com pesquisas realizadas em outros centros brasileiros, como no CPPL do Recife, no Centro Lydia Coriat em Porto Alegre, no Hospital Pinel do Rio de Janeiro e na Pré-Escola Terapêutica Lugar de Vida do Instituto de Psicologia da USP, que se baseiam em outros estudos realizados fora do Brasil, vêm produzindo um quadro muito rico que nos permite afirmar, hoje, que o autismo é um verdadeiro paradigma da subjetividade humana.

Em segundo lugar, a partir da teoria psicopatológica da humanidade, formulada por Freud, alguns problemas a respeito da angústia ainda precisam ser pesquisados.

Ainda no Dicionário comentado do alemão de Freud (1996), Luiz Hanns argumenta que o campo semântico coberto pelo vocábulo Angst cobre todas as formas de medo que vai de um sentimento de perigo indeterminado até um sentimento bastante determinado em relação a um dado objeto. Assim, Angst é medo.

Entretanto, se levarmos em consideração tanto a concepção de pulsão como força própria do ser vivente, como a noção de identificação primitiva que inclui a natureza irrepresentável, então é possível pensar numa angústia que não se submete ao campo semântico coberto pelo medo. Trata-se de um fenômeno produzido pela catástrofe glacial e que se inscreve diretamente no corpo graças ao primeiro movimento identificatório da libido e que faz parte do registro natural. Qual o nome dado a essa angústia irrepresentável? Provavelmente, a manifestação dessa angústia irrepresentável seja a dor.

A dor ainda precisa ser melhor estudada e o projeto de Claudia Gigante Ferraz, que está sendo desenvolvido no Laboratório de Psicopatologia da PUCSP, poderá trazer contribuições para a compreensão desse fenômeno primitivo.

Sabe-se que a dor é um fenômeno universal e irrestrito. O vasto consumo de analgésicos e entorpecentes é um eloqüente testemunho de que a humanidade é uma espécie dolorida. A psicanálise, por sua vez - porque a dor não se representa - tem crescente dificuldade em tratá-la porque enfrenta grandes dificuldades diante do representante coisa. Porém, Freud possuía uma teoria sobre a dor (cf. Aubert, 1996 e Nasio, 1997) e Ferenczi contribuiu, de forma decisiva, para uma clínica psicanalítica baseada numa noção de transferência do irrepresentável. Claro que o tratamento psicanalítico da dor enfrenta a dificuldade de se conceber a transferência do irrepresentável que é própria da natureza humana. Essa concepção de transferência aponta para uma clínica muito diferente da que se restringe à transferência por palavra. Fédida (1996) é, talvez, o psicanalista da atualidade que mais tem pensado a transferência como um fenômeno da natureza própria do homem e que não se representa pela palavra. Assim, pode-se dizer que a dor é parte inerente da Psicopatologia Fundamental 


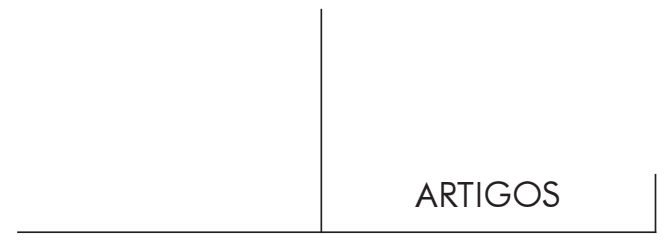

e de uma noção de sujeito que leva em consideração a biologia e não somente o significante.

Em terceiro lugar, de que forma a violência contida na catástrofe glacial se inscreve no humano? A violência contemporânea é uma simples repetição da violência primitiva ou ela é necessária para que, a cada vez, o homem se constitua como tal? Onde termina a violência necessária e começa a violência-repetição que é um sintoma, ou seja, uma manifestação da natureza cronificada do humano e uma tentativa de superar essa cronificação? Como transformar a violênciarepetição em uma experiência? É possível dar palavra à catástrofe? Ferenczi, novamente, preocupou-se com a possibilidade e a impossibilidade da representação do trauma. Aqui, mais perto de nós, Arthur Nestrovski, na PUC de São Paulo, vem se preocupando, há alguns anos, com a catástrofe e a representação. Sua pesquisa, que investiga o Shoah, revela elementos muito importantes para a compreensão do trauma psíquico e sua possível representação. No Laboratório de Psicopatologia Fundamental da PUC de São Paulo, Isabel Kahn Marin vem se dedicando à violência na constituição da subjetividade, e sua pesquisa pode vir a ser importante contribuição nesse campo. (cf. Nestrovski, 1998 e Marin, 1999)

É importante observar, em quarto lugar, que a catástrofe glacial produziu um enorme investimento libidinal na boca e no seio materno que adquiriram enorme importância com a crescente escassez de alimentos no período. O que hoje denominamos de distúrbios da oralidade foram, certamente, invenções daquele período já que estão quase que invariavelmente voltados para uma satisfação nirvânica. Assim, por exemplo, a angústia possui íntimas ligações com a boca e com a respiração. A anorexia, a bulimia, a drogadição podem, perfeitamente, encontrar suas origens nessa fase da humanidade. A pesquisa que vem sendo desenvolvida por Ana Cecília Magtaz Scazufca (1998), no Laboratório de Psicopatologia Fundamental da PUC-SP, contribui para uma melhor compreensão da anorexia e da bulimia na contemporaneidade. As investigações de Claudio Eugenio Marco Waks (1997) e de Marta Conte (1997), ambas também em desenvolvimento no Laboratório de Psicopatologia Fundamental da PUC-SP, devem trazer contribuições relevantes em direção à especificação de um paradigma da adição que possui numerosas ressonâncias filogenéticas.

Em quinto lugar, é necessário observar, também, que no primeiro período angustiado da humanidade ainda não havia fala, ou melhor, não havia pronunciamento de palavra porque esta ainda não havia sido criada. Além disso, provavelmente o aparelho fonador simplesmente não existia. Sabe-se que tanto a histeria de angústia como a de conversão são eminentemente expressivas, e até mesmo quando elas tomam a palavra é para fazer desta uma expressão e não uma significação. O principal problema psicopatológico da histeria é, portanto, 


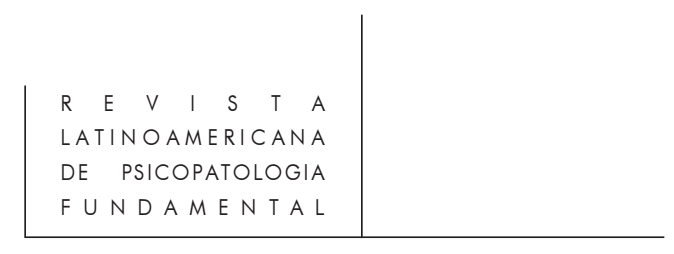

o de sua transformação numa experiência já que a palavra é utilizada como expressão e não como significação. Entende-se, assim, porque nos falta a palavra quando vivenciamos eventos catastróficos e nossas primeiras reações são movimentos corporais muito semelhantes a ataques histéricos.

Finalmente, mas não menos importante, a questão filogenética nos remete a um problema da mais alta importância: o da transformação do cérebro em mente, ou seja, como se deu a constituição do psiquismo a partir do cérebro.

A pesquisa que este problema suscita vem sendo realizada pelo Professor Doutor Gerald Edelman, Prêmio Nobel de Medicina em 1972 graças às suas contribuições para o conhecimento científico do sistema imunológico. O Dr. Edelman é diretor do Instituto de Neurociências e chefe do Departamento de Neurobiologia no Scripps Research Institute, da California, U.S.A.

De acordo com esse cientista, em Bright air, brilliant fire. On the matter of the mind (1992), houve época em que a linguagem foi associada à mente e, esta, desassociada do corpo. A mente permaneceu nas mãos dos psicólogos e o corpo nas dos biólogos. Esse divórcio, entretanto, provocou grandes prejuízos para o conhecimento científico. Edelman coloca, então, a mente de volta à natureza explorando como a consciência e o pensamento emergiram da evolução do cérebro humano. Ele argumenta que a mente é o produto de uma evolução neuronal. Edelman, reconhecendo a influência de Darwin e de Freud, propõe que o conflito e a mutação são os dois mecanismos responsáveis pela passagem do cérebro à mente. Com esta e outras importantes descobertas, Edelman pretende obter um segundo Prêmio Nobel.

Falta, entretanto, no brilhante raciocínio desenvolvido por Edelman, um elemento fundamental no movimento evolucionista que promove a emergência da mente a partir do cérebro. Trata-se do investimento libidinal que é responsável pela criação de morfologias e funções biológicas, como já demonstraram Ferenczi e Freud.

É possível que na fase angustiada da humanidade, com as primeiras identificações, tenha ocorrido um investimento libidinal tanto no cérebro como no futuro aparelho fonador do primata que, mais tarde, resultou na palavra.

\section{Conversão, perversão e hipocondria}

Com a continuação dos tempos difíceis, o homem primitivo, ameaçado em sua existência, precisou resignar-se diante do conflito entre a autopreservação e o prazer de procriar, o que encontra expressão na maioria dos casos típicos de histeria. Os gêneros alimentícios não eram suficientes para permitir um aumento das hordas humanas, e as forças individuais eram insuficientes para manter vivos os desamparados. A matança dos recém-nascidos certamente encontrou resistência 


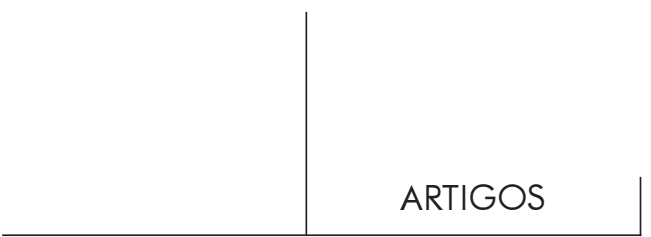

no amor, particularmente das mães narcisistas. Daí, a limitação da procriação tornouse um dever social. As satisfações perversas, que não levam à procriação, escaparam às proibições, o que promoveu uma certa regressão para a fase de libido anterior ao primado dos genitais. A limitação tinha de afetar as mulheres mais duramente do que aos homens, estes menos preocupados com a conseqüência da relação sexual. Essa situação toda corresponde, evidentemente, às condições da histeria de conversão. Da sintomatologia da mesma deduzimos que o homem ainda não possuía a fala, quando, vencido pela necessidade, se impôs não procriar, portanto, ainda não havia erguido o sistema pcs acima do ics. Sob a influência das proibições, regridem para a histeria de conversão os que estiverem com essa disposição, especialmente a mulher. Essas proibições pretendem desligar a função genital, enquanto impressões precoces, muito estimulantes, pressionam para a atividade genital. (pp. 65)

Ora, a histeria de conversão é, segundo Freud, uma segunda grande invenção da humanidade ameaçada em sua existência pela continuação da catástrofe glacial. A catástrofe, provocando a retirada do investimento libidinal no objeto, produz um refluxo que se desloca para e no próprio corpo e investe certos órgãos - na verdade, qualquer parte do corpo - como objeto. A grande invenção que nesta fase da humanidade se realiza é, portanto, o deslocamento do investimento libidinal de um objeto genital, isto é, responsável natural pela reprodução ampliada da espécie para um outro objeto, não genital e não natural, capaz de provocar prazer. Esse mecanismo é, hoje, denominado de perversão, mas Freud, em sua teoria psicopatológica da humanidade, não fala de uma fase perversa, pois, na sua ótica, não há como separar perversão de histeria de conversão, ou melhor, a histeria de conversão, à medida que investe libidinalmente um órgão qualquer, retira prazer daí e, assim, pode ser considerada perversão. Nessa ótica evidencia-se, mais uma vez, a concepção naturalista de Freud. A perversão é resultado de mutação que, por sua vez, é provocada pelo conflito, ou melhor, pela catástrofe. Trata-se, portanto, de uma grande invenção biológica que permite a sobrevivência da espécie. O prazer de órgão não genital reduz sensivelmente o sofrimento provocado pela catástrofe e, ao mesmo tempo, desvia a atenção do homem da reprodução que, naquelas circunstâncias, era extremamente ameaçadora para a espécie que enfrentava grande escassez de recursos para a sua manutenção. Forma-se, assim, o corpo erógeno e o psiquismo torna-se mais complexo, ainda que continue exclusivamente expressivo. A crescente complexidade do psiquismo se deve à sua capacidade de representação de objetos-órgãos investidos de libido. O corpo erógeno, ao contrário da concepção orgânica de corpo, não constitui um organismo, mas trata-se de uma superfície de órgãos com grande proximidade uns dos outros. O prazer perverso derivado de partes do corpo não é, portanto, narcisista, ainda que tenha íntima relação com 


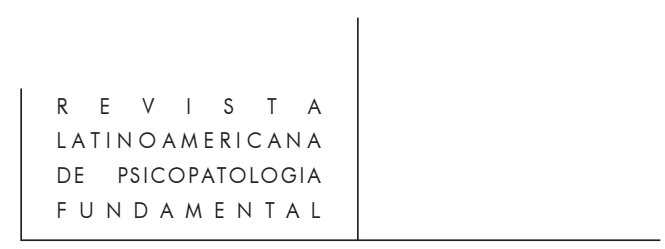

o narcisismo devido ao investimento realizado por mães narcisistas. Trata-se, sim, de um proto-narcisismo primário pois o corpo erógeno é a base do eu, mas falta, ainda, a sensação de organização própria do eu-corpo. Essa unidade corporal que é o eu depende da fase do espelho pesquisada por Lacan que pode, muito bem, encontrar suas origens filogenéticas nesse período conversivo da humanidade. Finalmente, é necessário observar que Freud não inclui o homossexualismo nessa fase da humanidade ainda que, na histeria de conversão, haja práticas homossexuais. Porém, a homossexualidade, para Freud, é uma invenção psicopatológica que pertence à fase obsessiva da humanidade.

Em outras passagens Freud dirá que a histeria de conversão recalca fantasias perversas e que a neurose é o negativo da perversão. Essas afirmações revelam a íntima relação existente entre a histeria e a perversão. Porém, em outros trabalhos, como "Três ensaios sobre a teoria da sexualidade" (1905/1972), Freud concebe a perversão como parte de uma ampla pesquisa infantil sobre o prazer e a reprodução.

Aqui é possível imaginar que a humanidade entre numa fase hipocondríaca onde o narcisismo exacerbado procura estabelecer um controle sobre a conversão acabando por conceber cada órgão do corpo como um pênis. (cf. Freud, 1998).

22 A hipocondria, ainda pouco estudada, se funda numa concepção erógena do corpo, define uma estética e lança o humano na drogadição. Trata-se, agora, de garantir que o campo erógeno denominado corpo tenha não só um aspecto fálico, mas, também, que os afetos - depressão, dor, angústia - sejam devidamente controlados com recursos obtidos da natureza. Foi provavelmente nesse momento da história psicopatológica filogenética da humanidade que se concebeu, pela primeira vez, a doença e a saúde que passam a reger a dinâmica corporal.

A este respeito é necessário que se diga que tanto a pesquisa realizada por Contardo Calligaris (1993), que resultou em tese de doutorado defendida na Universidade de Provence Aix-Marseille, como a de Carlos Augusto Peixoto Jr. (1997), que também resultou em tese de Doutorado defendida, com brilhantismo, no Instituto de Medicina Social da Universidade Estadual do Rio de Janeiro, trazem diversas contribuições importantes para a compreensão da perversão como prática social. Entretanto, essas pesquisas possuem uma concepção muito peculiar de perversão que não se baseia na idéia de conversão. Elas trabalham com uma outra perversão que decorre de uma falha no complexo de Édipo e que é, propriamente, pertencente ao homossexualismo. Pode trazer outros elementos para o entendimento dessa psicopatologia na ótica abordada por Calligaris e Peixoto Jr., pesquisa sobre o discurso perverso que está sendo realizada no Laboratório de Psicopatologia Fundamental da PUC-SP, por Edilene Freire de Queiroz, da 


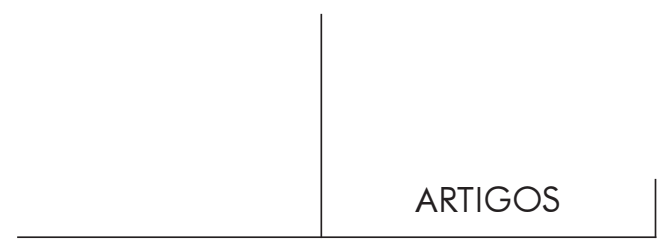

Universidade Católica de Pernambuco. Falta, assim, pesquisa sobre a perversão entendida como vicissitude da conversão que poderia trazer importantes contribuições para a melhor compreensão sobre as doenças orgânicas e as chamadas psicossomáticas.

A primeira conseqüência que a grande invenção da histeria de conversão coloca é, portanto, o da perda definitiva de contato com a regularidade sexual e a transformação do ato reprodutivo num ato prazeroso. Essa ocorrência produz uma transformação na natureza do aparelho genital que passa, a partir daí, a ser, também, um objeto parcial de prazer. Ora, assim entendida, a heterossexualidade pode ser tão perversa como qualquer perversão, já que esta é entendida como uma fixação do prazer num determinado objeto parcial, ou melhor, num órgão do corpo. A fixação, devemos sempre lembrar, é um sintoma porque é uma tentativa de repetição de um estado nirvânico para sempre perdido com a catástrofe glacial. Mas é, também, uma grande invenção defensiva contra ataques externos e internos ao organismo e ao psiquismo. Com a histeria de conversão, cada parte do corpo humano se transforma num objeto de prazer. Não há mais nenhuma razão para a primazia da heterossexualidade que passa a ser um problema, talvez maior do que a própria perversão.

$\mathrm{Na}$ contemporaneidade, uma das questões que se coloca para a histeria de conversão é a da lesão de órgão. Repetidamente é dito que a histeria de conversão não produz lesão de órgão. O próprio Freud insiste nessa afirmação, pois, em sua ótica, a conversão é uma defesa psíquica. Entretanto, na atualidade, observase que os portadores de histeria de conversão se oferecem para o saber médico que realiza atos cirúrgicos que produzem lesão de órgão. Assim, por exemplo, não há, no Brasil, dados precisos sobre o número de cesarianas praticadas, mas sabe-se que é um número muito maior do que as que seriam rigorosamente necessárias. Cirurgias que extirpam úteros são também praticadas muitas vezes sem necessidade, a não ser para certos médicos que, assim, ganham a vida. Ora, sabe-se que as questões atinentes ao útero são intimamente relacionadas à histeria de conversão. Mas há, aqui, um elemento propriamente social que remete à perversão tal como é concebida por Contardo Calligaris e por Carlos Augusto Peixoto Jr. Como diferenciar, então, a histeria da perversão? Num texto notável de Georges Didi-Huberman, denominado Invention de l'hysterie. Charcot et l'iconographie photographique de la Salpêtrière (1982), fica evidente a natureza perversa da histeria de conversão.

Um outro aspecto psicopatológico ainda pouco estudado - e intimamente relacionado com a histeria de conversão - é o das chamadas doenças psicossomáticas. Será que as chamadas doenças psicossomáticas são histeria de conversão com lesões de órgãos? Em Tempo de despertar (1973/1997) Oliver Sacks realiza um admirável estudo nosográfico sobre a doença do sono que 


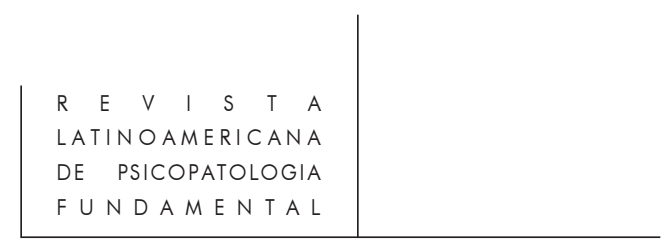

produz diversas conseqüências. Uma delas é a doença de Parkinson e Sacks argumenta, de forma extremamente cuidadosa e sensível, que essa doença neurológica muito provavelmente se trata de uma histeria de conversão com lesão neurológica.

Todos esses elementos apontam para o fato de que a histeria de conversão é, ainda, muito pouco estudada e pouco se sabe sobre sua dinâmica. Essa falta de pesquisa inteligente sobre a histeria de conversão deve-se, mais uma vez, à cisão entre a biologia, a medicina e a psicologia que afetou a psicanálise.

As pesquisas que estão sendo desenvolvidas por Milton Lopes de Souza (1998), na Faculdade de Ciências Médicas da Universidade Estadual de Campinas (UNICAMP) e no Laboratório de Psicopatologia Fundamental da PUC-SP revelam que partes do corpo, como a tireóide, podem ser investidas de um gozo que é capaz de provocar lesões de órgão, numa concepção estritamente médica, e que essas lesões podem se alterar com intervenções interpretativas próprias da técnica psicanalítica.

Enfim, pesquisas mais sistemáticas, precisas e claras a respeito da histeria de conversão ainda estão por serem feitas e, certamente, abririam diversos caminhos clínicos importantes que se relacionam com a concepção erótica do corpo e de suas partes, e os usos e abusos que se faz dele visando um prazer que tem, como horizonte primeiro, o estado edênico e que traz, junto, identificações primitivas com a violência e a destrutividade próprias de um período catastrófico constitutivo da humanidade do homem. Essas pesquisas incluem, evidentemente, a perversão como um sintoma conversivo e não como uma estrutura psíquica independente como se pensa hoje. A perversão concebida como conversão restabelece a naturalidade biológica desse fenômeno.

\section{A obsessão}

Mas voltemos, mais uma vez, à teoria psicopatológica da humanidade formulada por Freud.

O desenvolvimento seguinte, diz ele, é fácil de construir. Refere-se principalmente ao homem.

Depois de ter aprendido a poupar sua libido e a reduzir sua atividade sexual através da regressão a uma fase anterior, a inteligência ganhou para ele o papel principal. Aprendeu a pesquisar, a entender de alguma maneira o mundo adverso e a assegurar para si, através das invenções, um primeiro domínio sobre esse mundo. Desenvolveu-se sob o signo da energia, formava os princípios da linguagem e precisava prestar grande importância às novas conquistas. A linguagem era para ele magia; seus pensamentos pareciam-lhe onipotentes; compreendia o mundo através de seu próprio eu. 


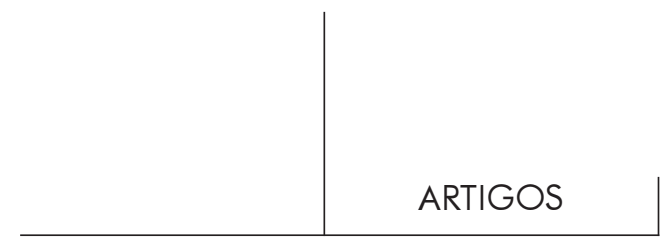

É a época da concepção anímica do mundo e de sua técnica mágica. Como recompensa pelo seu poder de proporcionar proteção e vida a tantos desamparados, arrogava-se domínio ilimitado sobre eles, defendendo, através de sua personalidade, as duas primeiras normas: sua inviolabilidade e que não pudesse ser negado a ele dispor das mulheres. No fim dessa época, a humanidade era dividida em hordas isoladas, as quais eram dominadas por um homem sábio, forte e brutal, como pai. É possível que a natureza desconsiderada, ciumenta e egoísta, que as ponderações da psicologia popular atribuem ao pai primitivo da horda humana, não existissem desde o começo, senão que, adaptando-se às necessidades, moldaram-se no percurso dos difíceis tempos glaciais.

Ora, a neurose obsessiva repete as características dessa fase da humanidade, uma parte da mesma de forma negativa já que a neurose, na configuração da formação de suas reações, também representa a resistência contra esse retorno. São traços não modificados: acentuação exagerada do pensar; a energia gigantesca retornando na compulsão; a onipotência do pensamento; a tendência para leis invioláveis. Porém, contra os impulsos brutais, os quais querem substituir a vida sexual, opõe-se a resistência de desenvolvimentos posteriores. Estes partem do conflito libidinal, paralisam a energia vital do indivíduo e consistem apenas naqueles restos de impulsos através da obsessividade, deslocados para insignificâncias. Assim como o tipo grandioso do pai primitivo, que realmente sucumbiu nas relações familiares criadas por ele próprio, ressuscita depois como divindade, assim também sucumbe esse tipo humano, o mais valioso para o desenvolvimento da cultura, em seu retorno, diante das exigências da vida sexual. (pp. 77-78)

A fase obsessiva da humanidade é vista, então, como uma outra grande invenção que constitui o pai primitivo. Este é responsável, diante da perda da regularidade sexual e da ameaça que essa produz para a existência da espécie, pela invenção da palavra e da fala. Em "Função e campo da transferência na psicanálise", publicado no Boletim de Novidades da Livraria Pulsional (Berlinck, 1995) encontra-se o mito psicopatológico da origem da palavra contido na fase obsessiva da teoria psicopatológica da humanidade proposta por Freud.

Como já foi escrito anteriormente, enquanto macho e fêmea - hominídeo e hominídea - mantiveram contato com a regularidade sexual, não houve necessidade de recurso à palavra. A regularidade sexual era assegurada pelo olfato, já que o macho reconhecia por esse sentido humano o período de fertilidade da fêmea. Esse período da filogênese caracteriza-se também por um verdadeiro equilíbrio eco-psíquico que dispensa a palavra.

Trata-se de um delicioso mundo habitado pelo silêncio. Tal situação de equilíbrio veio, entretanto, ser perturbada por distúrbios glaciais que provocaram o resfriamento da crosta terrestre e puseram em risco a sobrevivência da espécie. Diante desses distúrbios glaciais, macho e fêmea se viram na contingência de assumir posição bípede para obterem, de arbustos e árvores, o alimento neces- 


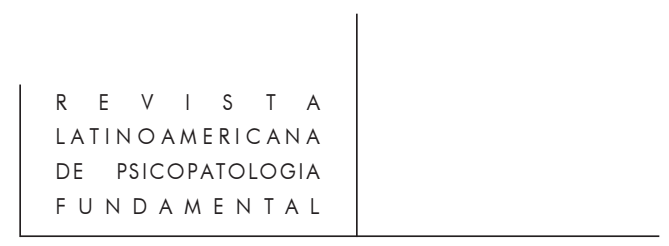

sário à sua sobrevivência. Essa alteração de postura provocou também uma alteração na capacidade olfativa, fazendo com que o macho perdesse contato com a regularidade sexual. Essa vicissitude da posição bípede vai colocar novamente em ameaça a sobrevivência da espécie, e o macho é levado a buscar e encontrar um sistema que possibilite reconhecer o período de fertilidade da fêmea. Nasce, dessa forma, o símbolo, que só adquire estatuto de palavra quando se encontra com a mentira própria da fêmea solicitada pelo prazer. O encontro do símbolo com a mentira, que representa por excelência a mulher, produz a polissemia que é inerente à palavra e que a distingue daquele. A esse trabalho inteligente de criação do símbolo que resulta na palavra adiciona-se, também, um longo e persistente controle sobre as cordas vocais que implica num investimento libidinal que, por anfimixia, vai resultar na voz humana. Essa construção filogenética da voz só é compreensível à luz da leitura de Thalassa (1990). O investimento na voz se dá por um deslocamento possibilitado pela libido poupada e pela redução da atividade sexual. Baseia-se, portanto, na fase de histeria de conversão.

A prática clínica pode nos levar então a reconhecer, no ato falho, uma perturbação no controle da voz que suscita a escuta filogenética e remete o psicanalista e o sujeito a momentos em que o humano ainda não tinha o domínio tão desenvolvido de suas cordas vocais e, muito menos, da palavra.

Não sabemos em que momento da história filogenética psicopatológica da humanidade o ser humano começa a sonhar. Como o sonho é concebido por Freud como uma psicose controlada, é possível que ele tenha se constituído como fenômeno psíquico só depois do assassinato do pai da horda. Porém, é possível, também, que o sonho e o humor produzidos pelo ato falho e pela ironia tenham sido uma invenção do pai primitivo. De qualquer forma, o sonho, assim como o desejo, tal como é concebido hoje, só passa a ser uma formação psíquica a partir do momento em que o primata se vê na contingência de buscar a fêmea para a reprodução-prazer. O sonho e o desejo são, portanto, muito provavelmente, contemporâneos da invenção da palavra e da fala já que essas três formações psíquicas supõem não só a perda de contato com o objeto e o estabelecimento da vivência do prazer, mas, também, a mentira da hominídea que introduz a polissemia no símbolo e permite a alucinação.

De qualquer forma, na ótica da teoria psicopatológica da humanidade, não há muito espaço para se pensar um eventual declínio da função paterna que estaria ocorrendo na contemporaneidade. A chamada função paterna é uma herança que se inscreve no psiquismo humano a partir do assassinato do pai da horda. Essa função, como observa Freud, enfrenta sempre uma oposição dos familiares. Essa dinâmica se repete até hoje.

Falar, portanto, de um declínio da função paterna é supor um avanço da família - essa instituição psicopatológica por excelência - sobre o pai e uma 


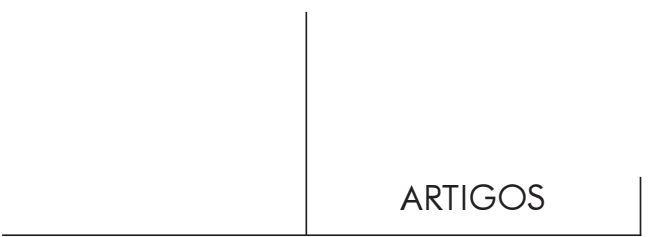

alteração de qualidade no psiquismo humano que estaria ocorrendo só na contemporaneidade, sendo também necessário reconhecer que nunca a humanidade foi tão inventiva. Criar o pai, viver o pai, matar o pai é uma dinâmica própria da natureza psicopatológica do ser humano e uma herança filogenética.

$\mathrm{Na}$ teoria psicopatológica da humanidade, a predominância do pai e seu assassinato encerra o ciclo das neuroses de transferência e inaugura o ciclo das neuroses narcisistas.

\section{Esquizofrenia, paranóia e melancolia}

Elas ocorrem, assim, na segunda geração, cujo desenvolvimento nos transporta para uma nova fase do desenvolvimento psicopatológico da humanidade.

Essa segunda geração começa com os filhos, aos quais o pai primitivo, ciumento, nada permite. Ele os expulsa quando chegam à idade púbere, em substituição a essa solução. A experiência da psicanálise nos adverte, porém, sobre uma outra, ainda mais cruel, isto é, a de que ele os despoja de sua virilidade, podendo dessa forma permanecer na horda como inofensivos trabalhadores auxiliares. Podemos certamente imaginar o efeito da castração naquele tempo primitivo como uma extinção de libido e uma parada no desenvolvimento individual. A demência precoce parece repetir esse estado de coisas, e, principalmente na forma hebefrênica, leva à desistência de qualquer objeto de amor, involução de todas as sublimações e volta ao auto-erotismo. O jovem comporta-se como se tivesse sofrido a castração; na verdade, não são raras as autocastrações reais nessa afecção. Os outros aspectos da doença, como as alterações da fala, os surtos alucinatórios, não devem ser referidos ao quadro filogenético, pois correspondem à tentativa de cura, aos diversos esforços para recuperar o objeto, os quais, durante algum tempo, no quadro sintomático da doença, quase se destacam mais do que os fenômenos da regressão.

Há uma questão ligada a tal tratamento dispensado aos filhos que deve ser respondida de passagem. Como ocorreriam a sucessão e a substituição dos pais primitivos, caso se livrassem dos filhos dessa maneira? Já Atkinson (1903) mostrou o caminho, destacando que somente os filhos mais velhos tinham de temer as perseguições do pai. Enquanto o mais jovem - de maneira esquemática - graças à intercessão da mãe e, antes de mais nada, pelo envelhecimento do pai e de seu conseqüente desamparo, tinha a chance de escapar a esse destino e tornar-se sucessor do pai. Esta preferência pelo mais jovem foi basicamente afastada na estrutura social subseqüente e substituída pelo privilégio do mais velho. No mito e no conto de fadas, contudo, permanece ainda bem reconhecível.

O passo seguinte poderia consistir apenas na fuga dos filhos ameaçados de castração, aprendendo a assumir, juntos, a luta pela vida. Essa convivência tinha 


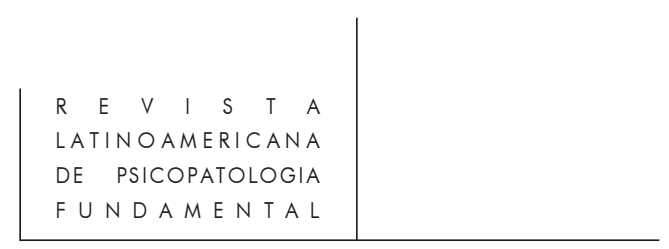

de produzir os sentimentos sociais e podia estar edificada na base de satisfações homossexuais. É bem possível que nos deparemos com a tão procurada disposição hereditária à homossexualidade na transmissão das condições dessa fase. Os sentimentos sociais, assim produzidos na sublimação da homossexualidade, tornamse mais tarde propriedade permanente da humanidade e a base de toda sociedade futura. A paranóia recupera visivelmente as condições dessa fase; melhor dito, a paranóia defende-se contra o retorno da mesma, na qual não faltam alianças secretas e o perseguidor representa um magnífico papel. A paranóia tenta repelir a homossexualidade, que era a base dessa fraternidade e, ao mesmo tempo, tem de expulsar da sociedade o acometido de homossexualidade e destruir suas sublimações sociais.

A classificação da melancolia-mania nesse contexto esbarra com a dificuldade de que não é possível determinar com certeza a época normal para o aparecimento individual desses sofrimentos neuróticos. Mas, seguramente, é mais na idade adulta do que na infância. Se observarmos bem a mudança característica da depressão para a euforia, é difícil não nos lembrarmos da sucessão semelhante de triunfo e luto que forma o conteúdo regular das festividades religiosas. Luto pela morte de Deus; alegria triunfal na sua ressurreição. Concluímos, a partir do que afirma a psicologia dos povos, que esse cerimonial apenas repete na direção inversa o comportamento da fraternidade, após terem dominado e matado o pai primitivo; triunfo sobre sua morte e em seguida luto, pois todos o admiravam como tipo ideal. Assim, esse grande acontecimento da história da humanidade, que pôs fim à horda primitiva e a substituiu pela fraternidade vitoriosa, daria origem às predisposições da peculiar sucessão de estado de ânimo que reconhecemos como particulares afecções narcisistas ao lado das parafrenias. O luto pelo pai primitivo emana da identificação com ele, e tal identificação provamos ser a condição do mecanismo da melancolia.

Resumindo, podemos dizer o seguinte: se as disposições para as três neuroses de transferência foram adquiridas na luta contra as necessidades dos tempos glaciais, então as fixações, nas quais se baseiam as neuroses narcisistas, originaram-se da opressão do pai, o qual, após o término da era glacial assume, continua, por assim dizer, tal papel contra a segunda geração. Da mesma forma como a primeira luta leva para a fase cultural patriarcal, a segunda leva à social. Ambas, contudo, produzem as fixações, as quais, em seu retorno, após milênios, transformam-se nas disposições dos dois grupos de neurose. Portanto, neste sentido, a neurose é também uma aquisição cultural. (pp. 78-80)

A fase psiconeurótica da humanidade é inaugurada com o envelhecimento e o assassinato do pai da horda e é marcada por essa figura tão admirada por Freud.

Em primeiro lugar, o assassinato do pai da horda é acompanhado por sua devoração. Trata-se, portanto, de um ritual com fortes componentes orais. A anorexia, que inicialmente foi associada à histeria de angústia e que é 


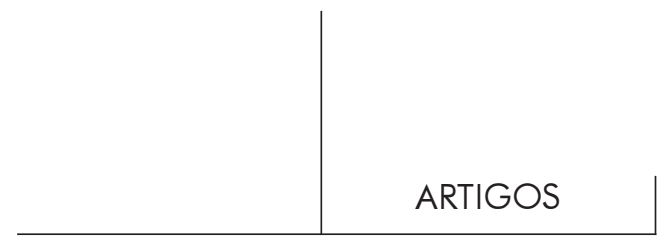

freqüentemente curável enquanto sintoma histérico, adquire, aqui, outras características. É possível que certas fêmeas tenham se recusado a devorar o pai, que era também amante, e esse ato pode ter produzido conseqüências avassaladoras nas práticas alimentares e na imagem de corpo que daí se forma. A recusa em devorar o pai pode ter produzido um enorme prazer no jejum como forma de purificação e de ideal. A filha amada não come o pai assassinado e conserva sua pureza. Não comer passa, assim, a ser um ideal e o sinal dessa pureza ideal é o corpo sem carne, só pele e osso. A bulimia, por sua vez, pode ser vista como falha na devoração do pai. A bulímica come o pai assassinado e imediatamente se arrepende do ato, produzindo vômito. Nesta ótica, tanto a anorexia como a bulimia são neuroses narcísicas muito mais difíceis de serem tratadas do que as crises histéricas de anorexia e bulimia anteriormente descritas. Neste segundo caso, um tratamento mal conduzido leva à morte das anoréxicas, pois estas preferem morrer a perder sua pureza ideal. Já isso não ocorre com as bulímicas pois estas se afastam ligeiramente do ideal graças à falha da gula primitiva.

De qualquer forma, o investimento libidinal solicitado pela devoração do pai da horda produz uma série de interessantes fenômenos que começa com o canibalismo e passa pela anorexia e a bulimia.

Em segundo lugar, a castração passa a ser a marca mais importante da fase patriarcal que termina com o assassinato do pai da horda. A castração é, primeiro, real e só depois passa a ser imaginária e simbólica. Aqui, novamente, Freud insiste no fundamento biológico daquilo que se torna psíquico. Trata-se, sempre, de um processo evolutivo natural, ou seja, baseado no conflito e na mutação como fenômenos da natureza. A ameaça da castração, por sua vez, produz a passividade, a submissão e o homossexualismo. Nesta visão, o homossexualismo é o principal fundamento da sociedade humana, pois esta nada mais é do que homossexualidade sublimada. A homossexualidade é, portanto, uma grande conquista cultural que permite o aparecimento e o desenvolvimento das relações sociais. Para Freud, novamente, o que seria propriamente psicopatológico no homossexualismo é a fixação da sexualidade nessa fase. Entretanto, há um sofrimento, uma dor, um pathos no homossexualismo que depende da passividade, da submissão a uma figura brutal e violenta que é muito ameaçadora. De qualquer forma, a partir dessa concepção peculiar, numerosas portas clínicas e metapsicológicas se abrem para o tratamento do homossexualismo e para uma compreensão mais adequada desse fenômeno, que praticamente ainda não foram exploradas. Em primeiro lugar, os psicanalistas vêm se referindo ao homossexualismo como uma perversão. Esta concepção está longe da de Freud que vê, no homossexualismo, uma das vicissitudes da castração real primitiva e um fundamento da sociedade humana. A repetição da homossexualidade, nesta 


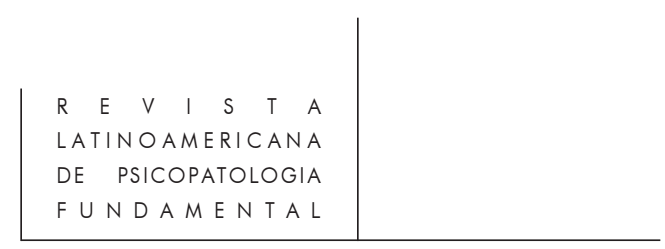

perspectiva, é uma fixação que suscita uma dificuldade no relacionamento social, já que falta, nesse caso, uma sublimação que leva à sociabilidade. Essa concepção pode, por sua vez, ser muito útil para se compreender a freqüente marginalização e o preconceito que estão ligados ao homossexualismo e que se manifestam na fala de pacientes. Dessa concepção deriva-se, também, uma certa direção no tratamento do homossexualismo que não visa a dissolução dessa manifestação da sexualidade humana, mas um trabalho propriamente sublimatório a caminho de uma sociabilidade com menos sofrimento.

Pesquisas que vêm sendo realizada por Júlio Cesar Cordeiro do Nascimento e por Paulo Roberto Ceccarelli, no Laboratório de Psicopatologia Fundamental da PUC de São Paulo, podem trazer contribuições para uma compreensão mais precisa e clara do homossexualismo.

Em terceiro lugar, o assassinato do pai da horda e a constituição da sociedade humana colocam dois importantes problemas psicopatológicos. Em que medida a mulher se submete à castração? Esta pergunta, feita pelo próprio Freud, encontra seu fundamento natural na ordem constituída pelo pai da horda. A lei não é a do incesto, tal como formulada na contemporaneidade. $\mathrm{O}$ acesso às mulheres é franqueado ao pai primitivo. Assim, as filhas queridas se transformam em suas mulheres. A proibição se refere aos filhos e estes ou se submetem e são castrados ou constituem uma nova horda. Abre-se, dessa forma, um espaço inicial para a exogamia e para a troca de mulheres entre pais de hordas. Já foi dito que a anorexia e a bulimia são sintomas de mulheres e remetem à ordem em que eram filhas amadas e amantes do pai primitivo. Essa diferença em relação à castração é que permite se pensar, como diz o poeta Nelson Ascher: "o homem é o único animal cuja fêmea é de outra espécie" e que a feminilidade é uma posição outra em relação ao falo. A feminilidade, portanto, não é um conceito referido à mulher ou ao feminino. Mas se trata de uma posição outra em relação à ordem regida pelo complexo de castração.

O segundo problema suscitado pelo assassinato do pai da horda e a constituição da sociedade humana refere-se à família como paradigma institucional. Da horda à família há muito mais do que a civilização: há a psicopatologia. Abrese, dessa forma, um vasto campo de pesquisa sobre a instituição que vem sendo realizada pela análise institucional de forma ainda bastante incipiente já que, muitas vezes, esta tem sido invadida por ideologias políticas.

Dentre as numerosas possibilidades de compreensão da psicopatologia que a teoria psicopatológica da humanidade nos oferece, duas merecem ser destacadas aqui.

A primeira diz respeito ao desamparo como aquilo que permeia qualquer manifestação subjetiva. Nesse sentido, os trabalhos sobre o pânico que vêm sendo desenvolvidos e publicados por Mário Eduardo Costa Pereira (1997) no 


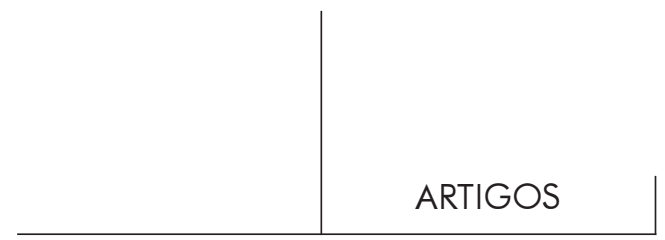

Laboratório de Psicopatologia Fundamental da UNICAMP, merecem ser citados. O desamparo, que se manifesta de forma tão evidente em nossas clínicas em praticamente todos os casos que tratamos, não tem somente referências às condições de vida contemporâneas. A angústia e o medo são sentimentos muito primitivos e assim devem ser escutados e tratados por aqueles que não estão interessados apenas na eliminação dos sintomas. Eliminar o pânico com medicamentos, sem respeitar a subjetividade humana, é, sim, uma grande desonestidade profissional, pois essa prática leva à cronificação da doença e à impossibilidade de sua transformação em experiência. Esse procedimento pode eliminar o pânico e criar a drogadição.

A segunda refere-se à natureza mesma do psiquismo humano. $\mathrm{O}$ chamado aparelho psíquico faz parte, nessa ótica, do sistema imunológico, pois se trata de uma organização que se desenvolve para proteger o ser humano de ataques destrutivos externos e internos. A catástrofe glacial, metáfora de um primeiro ataque que ameaça a espécie, leva o hominídeo e a hominídea a inventarem mecanismos defensivos que começam pela retirada da libido do objeto. Esta, uma vez retraída, passa a ser uma ameaça interna da qual o ser humano não pode fugir. Os mecanismos de defesa até agora inventados pelo homem fracassaram, apesar de terem sido grandes invenções. Estas, por sua vez, nesta ótica psicopatológica, dependem de novos ataques tanto internos como externos. Há, assim, uma dialética semelhante à existente entre o organismo e os vírus. Estes só existem no corpo e os órgãos atacados produzem defesas que nem sempre são eficientes porque os vírus sofrem mutações. Entretanto, certos sujeitos apresentam uma deficiência defensiva que é maior que o desamparo. Essa descoberta foi realizada no âmbito do Laboratório de Psicopatologia Fundamental da PUC-SP, graças às pesquisas de Ana Cleide Guedes Moreira e Renate Meyer Sanches, com pacientes portadores de vírus HIV. Gallo e Montagnier haviam observado que pacientes deprimidos morrem muito mais depressa do que os que não apresentam essa característica psicopatológica. Ana Cleide Guedes Moreira (1997) observou que não se trata propriamente de pacientes deprimidos, mas de pacientes melancólicos. Esta observação foi confirmada pela pesquisa de Renate Meyer Sanches (1997) e nos levou a conceber uma insuficiência imunológica psíquica (Berlinck, 1997) que é própria da alma humana. A insuficiência imunológica psíquica não só aumenta a vulnerabilidade do organismo a ataques virulentos, como impede que defesas sejam acionadas quando esses ataques ocorrem. A insuficiência imunológica psíquica, que se manifesta claramente em pacientes melancólicos que possuem uma grande capacidade destrutiva e autodestrutiva, possui ressonâncias de um tempo primitivo inaugurado pela destrutividade. O psiquismo é uma grande invenção humana que possui seus limites. Talvez a capacidade criadora do homem encontre, um dia, uma solução 
para essa insuficiência. Mas enquanto isso não ocorre, corremos o risco de inventarmos novos sintomas para velhas neuroses.

\section{Bibliografia}

Amar, Nadine; Le Guen, Annick et OpPenheimer, Agnès (orgs.). "Angoisses: pluralité d'approches". Monographies de la Revue Française de Psychanalyse. Paris, Presses Universitaires de France, 1997.

Aubert, Annie. La douleur. Originalité d'une théorie freudienne. Paris, Presses Universitaires de France, 1996.

Athanassiou, Cléopâtre. La défense maniaque. Paris, Presses Universitaires de France, 1996.

BerLINCK, Manoel Tosta. "Função e campo da transferência na psicanálise", in Boletim de Novidades da Livraria Pulsional, ano VIII, no 72, abril de 1995, pp. 11-23.

"Insuficiência imunológica psíquica", in Boletim de Novidades da Livraria Pulsional, ano X, no 103, novembro de 1997, pp. 5-14.

"O que é Psicopatologia Fundamental?", in Revista Latinoamericana de Psicopatologia Fundamental, ano 1, no 1, março de 1998, pp. 46-59.

Birman, Joel. "A epopéia do corpo", in BAstos, Liana Albernaz de Melo, Eu-corpando. O ego e o corpo em Freud. São Paulo, Escuta, 1998, pp. 9-24.

Brusset, Bernard; Couvreur, C. et Fine, A. (orgs.). "La boulimie". Monographies de la Revue Française de Psychanalyse. Paris, Presses Universitaires de France, 1991.

Brusset, Bernard et Couvreur, C. (orgs.). "La névrose obsessionnelle". Monographies de la Revue Française de Psychanalyse. Paris, Presses Universitaires de France, 1993.

Calligaris, Contardo Luigi. "Recherche sur la perversion comme pathologie sociale. La passion de l'instrumentalité", thèse pour le Doctorat Nouveau Régime en Lettres et Sciences Humaines, Université de Provence Aix-Marseille I, 1993.

Conte, Marta. "Da necessidade à demanda. Como viabilizar a transferência no tratamento dos toxicômanos", in Boletim de Novidades da Livraria Pulsional, ano X, no 103, novembro de 1997, pp. 33-41.

Cournut, Jean; IsRaËL, Paul; Jeanneau, Augustin et SCHAEFFER, Jacqueline (orgs.). "Le mal-être (angoisse et violence)". Monographies de la Revue Française de Psychanalyse. Paris, Presses Universitaires de France, 1997.

Didi-Huberman, Georges. Invention de l'hysterie. Charcot et l'iconographie photographique de la Salpetrière. Paris, Macula, 1982.

Edelman, Gerald M. Bright air, brilliant fire. On the matter of the mind. New York, Basic Books, 1992.

Ferenczi, Sándor. Thalassa. Ensaio sobre a teoria da genitalidade, trad. de Álvaro Cabral. São Paulo, Martins Fontes, 1914/1990.

Fine, Alain; Le Beuf, Diane et Le Guen, Annick (orgs.). "Bisexualité". Monographies 


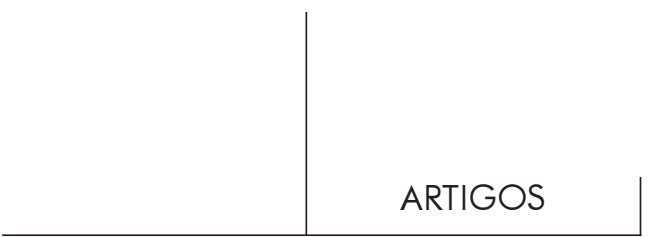

de la Revue Française de Psychanalyse. Paris, Presses Universitaires de France, 1997.

Freud, Ernest L. e Meng, Heinrich (orgs.). Cartas entre Freud \& Pfister - 1909-1939. Um diálogo entre a psicanálise e a fé cristã, trad. de Karin Hellen Kepler Wondrack e Ditmar Junge. Viçosa, Ultimato, 1998.

FreUd, Sigmund. "Três ensaios sobre a teoria da sexualidade", in ESB. Rio de Janeiro, Imago, 1905/1972.

Neuroses de transferência: uma síntese, trad de Abram Eksterman. Rio de Janeiro, Imago, 1914/1987.

“O mal-estar na civilização”, in ESB. Rio de Janeiro, Imago, 1930/1974, pp. 81-171.

HAnns, Luiz. Dicionário comentado do alemão de Freud. Rio de Janeiro, Imago, 1996.

Hölderlin, Friedrich. Hipérion ou O eremita na Grécia, trad. de Márcia C. de Sá Cavalcante. Petrópolis, Vozes, 1797/1994.

Le Guen, Annick; Oppenheimer, Agnès et Perron, Roger (orgs.). "Angoisse et complexe de castration". Monographies de la Revue Française de Psychanalyse. Paris, Presses Universitaires de France, 1991.

Magalhães, Cristina. "Narcisismo primário e o desejo", in Manoel T. Berlinck (org.). O desejo na psicanálise. Campinas, Papirus, 1985, pp. 27-44.

Marin, Isabel Kahn. "Indagações?...sexualidade", in Pulsional Revista de Psicanálise, ano XII, nº 118, fevereiro de 1999, pp. 65-71.

Mitrani, Theodore and Mitrani, Judith L. (eds.). Encounters with Autistic States. A Memorial Tribute to Frances Tustin. Northvale N.J., Jason Aronson, 1997.

Moreira, Ana Cleide Guedes. "Melancolia e AIDS: Da urgência de escuta do sintoma", in Boletim de Novidades da Livraria Pulsional, ano X, no 93, janeiro de 1997, pp. 23-36.

NAsio, Juan-David. O livro da dor e do amor, trad. de Lucy Magalhães. Rio de Janeiro, Jorge Zahar, 1997.

Nestrovski, A. "Vozes de crianças", in Pulsional Revista de Psicanálise, ano XI-XII, nos 116-117, dezembro de 1998-janeiro de 1999, pp. 85-97.

Pereira, Mário Eduardo Costa. Pânico. Contribuição à psicopatologia dos ataques de pânico, trad. de Celene Margarida Cruz, Clémence M.C. Jouët-Pastré, Edilene Cristina Marezzi e Renata Balarini Coelho. São Paulo, Lemos, 1997.

Peiхoto JR., Carlos Augusto. "Metamorfoses entre o sexual e o social. Uma leitura da teoria psicanalítica sobre a perversão", tese de Doutorado defendida no Instituto de Medicina Social da Universidade do Estado do Rio de Janeiro, 1997.

PIRLOT, Gérard. Les passions du corps. La psyché dans les addictions et les maladies auto-immunes: possessions et conflits d'alterité. Paris, Presses Universitaires de France, 1997.

SAcks, Oliver. Tempo de despertar, trad. de Laura Teixeira Motta. São Paulo, Companhia das Letras, 1973/1997.

Santos, Marília Amaro da Silveira Modesto. "A trajetória de um autista e suas implicações com a temporalidade", in Revista Latinoamericana de Psicopatologia 


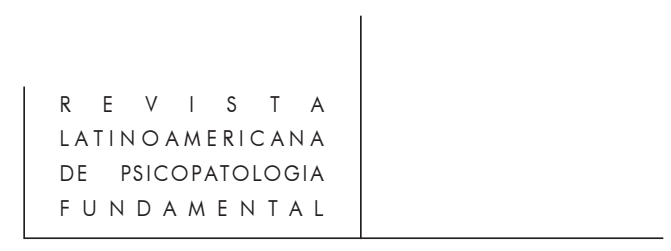

Fundamental, ano 1, no 1, março de 1998, pp. 122-140.

ScazufCA, Ana Cecília Magtaz. "Anorexia-Bulimia: sintomas do desejo", in Boletim de Novidades da Livraria Pulsional, ano XI, no 106, fevereiro de 1998, pp. 15-27.

Silva, Antonio Ricardo Rodrigues da. "O mito individual do autista”, in Rocha, Paulina Schmidtbauer (org.). Autismos. São Paulo, Escuta, 1997, pp. 27-38.

SouzA, Milton Lopes de. "Psicossomática: o usofruto do corpo", in Boletim de Novidades da Livraria Pulsional, ano XI, no 106, fevereiro de 1998, pp. 39-47.

Tustin, Frances. "A perpetuação de um erro", in Letra Freudiana, ano XIV, no 14 , 1995, pp. 63-79.

WAKs, Claudio Eugenio Marco. "O lixo clínico. A clínica psicanalítica da toxicomania", in Boletim de Novidades da Livraria Pulsional, ano X, nº 103, novembro de 1997, pp. 55-61.

\section{Resumos}

Este artículo comenta muy detalladamente, el trabajo de Sigmund Freud, "Neurosis de transferencia: una síntesis", que es considerado pelo autor como una teoría general de la naturaleza psicopatológica de la humanidad. Desde esta perspectiva, porque la humanidad está submetida al deseo, la pasión la torna psicopatológica. Entonces, a partir del pressupuesto de que lo humano es una especie psicopatológica, el autor hace comentários sobre la nosologia freudiana, su importancia en la actualidad y sus limitaciones, formulando, así, un amplio proyeto de pesquisa que está siendo desarrollado en el psicoanálisis.

Cet article commente, d'une manière détaillée, le travail de Sigmund Freud, Névrose de transfert: une synthèse, qui est considéré par l'auteur comme une théorie général de la nature psychopathologique de l'humanité. Dans cette perspective, puisque l'humanité est soumise au désir, la passion la rend psychopathologique. Donc, à partir du pressuposé selon lequel l'human est une espèce psychopathologique, l'auteur fait des commentaires sur la nosologie freudienne, son importance actuel et ses limitations, en formulant, ainsi, un ample projet de recherche qui est en train d'être developpé dans la psychanalyse.

This article contains detailed commentaries about Sigmund Freud's "Overview of the transfer neuroses", which is considered to be a general theory of the psychopathological natures of human kind. In this perspective, because human kind is submited to wish, passion turns the human a psychopathological species. From then on, the author presents commentaries about the freudian nosolofy, its actual importance and limitations, presenting a large research project that is under way in psychoanalysis. 